\title{
The late Paleocene event and a potential precursor compared: First results from Egypt
}

\section{ROBERT P. SPEIJER}

In Egypt, upper Paleocene stratigraphy and biota have been studied extensively with a particular focus on the regional expression of the late Paleocene thermal maximum (LPTM) and related global changes. Preliminary studies on the lower upper Paleocene (lower Selandian; Zone P3), here indicated as "middle" Paleocene, in Egypt reveal yet another potentially highly interesting interval. Similar to the LPTM interval, the "middle" Paleocene shows a level with peculiar changes in benthic as well as planktic foraminifera assemblages, which are associated with anomalous sedimentologic features (Table 1).

Background characteristics. - During the early Paleogene an extensive epicontinental basin covered Egypt, reaching maximum southward extension into northern Sudan during the late Paleocene. Basinal deposits consist of monotonous marls and occasionally limestones. Near local highs and along the basin's margins, these interfinger with platform carbonates and deltaic deposits. The marls which are generally low in TOC contain rich planktic foraminifera and calcareous nannoplankton assemblages, pointing to open connections to the Tethys. Planktic foraminifera assemblages (Zones P3-P5) are diverse, composed of the genera Morozovella, Acarinina, Igorina, Globanomalina, and Subbotina. Benthic assemblages, characterized by Midway (neritic) and mixed Midway-Velasco (bathyal) type faunas, are highly diverse, increasing with paleodepth. These assemblages indicate well to moderately oxygenated conditions at the sea floor. P/B ratios, generally vary between 60 and 95\%, but wherever there is evidence of severe post-mortem dissolution these may be much reduced. Physical discontinuities in the monotonous successions are rarely apparent, but are indicated by detailed biostratigraphic investigations.
Late Paleocene event. - Quite a different picture emerges in various Egyptian sections where a c. 1-m thick interval correlates with the LPTM. In the sections situated in the deeper parts of the basin, dark brown, finely laminated marl beds, often overlain by foraminifera-rich calcarenitic marl beds mark the interval comprising the CIE and BEE (see Speijer \& Schmitz this volume). The laminated beds are enriched in TOC (2-3\%) and contain abundant peloids - indicating condensation - and fish scales. In some profiles, the contact between this lithologic unit and the underlying monotonous marls is marked by bioturbated omission surfaces or channel fill, indicating discontinuities at the base of the CIE. The microbiota indicate anomalous paleoenvironmental conditions. Planktic foraminifera assemblages in the laminated interval are almost exclusively composed of Acarinina species. Morozovella allisonensis is the only common representative of its genus. The benthic assemblages in the same interval are oligotaxic, composed of a few opportunistic taxa capable of - occasionally? - populating a sea-floor under oxygen stress (see Speijer \& Schmitz this volume). These taxa invaded the entire basin from the shallower shelf. P/B ratios are extremely high (up to $99.9 \%$ ), a feature common to many Neogene to Holocene sapropels and attributable to the hostile sea-floor conditions.

"Middle" Paleocene event. - This event has been observed in four localities in the Eastern Desert, representing middle to outer neritic deposition. In the deeper Wadi Nukhl section a paraconformity marks this interval. Preliminary biostratigraphic data indicate that the event is situated within Zones P3a/NP4. Darkbrown laminated beds, rich in fish remains, together with beds very rich in foraminifera, mark an up to 2 -m thick interval. Sev-

Table 1. Comparison of biotic and sedimentary features between the early Selandian event (P3a/NP4), the late Paleocene event (mid P5), and background characteristics. Note that these features may not necessarily be present in every section studied.

\begin{tabular}{|c|c|c|c|}
\hline Parameter & Background P3/P5 & $\mathrm{P} 3 \mathrm{a} / \mathrm{NP} 4$ event $^{1}$ & LPTM $\left(\right.$ mid P5) ${ }^{2}$ \\
\hline Lithology & Marl & $\begin{array}{l}\text { Laminated marl and } \\
\text { foram-rich marl }\end{array}$ & $\begin{array}{l}\text { Laminated marl and } \\
\text { foram-rich marl }\end{array}$ \\
\hline Discontinuities & Some paraconformities & Some distinct & Some distinct \\
\hline Fish remains & Rare & Abundant & Abundant \\
\hline Peloids & Rare & Rare & Abundant \\
\hline Macrofossils & Rare & Shell stringers & Rare \\
\hline TOC & $<0.5 \%$ & $>1 \%$ & $>2 \%$ \\
\hline \multicolumn{4}{|l|}{ Foraminifera: } \\
\hline $\mathrm{P} / \mathrm{B}$ ratio $(>125 \mu \mathrm{m})$ & $60-95 \% \mathrm{P}^{3}$ & $<20 \%$ or $>95 \% \mathrm{P}$ & $>95 \% \mathrm{P}$ \\
\hline Morozovella & Common to abundant & Rare & Rare \\
\hline Non-keeled (prae)muricate taxa & Common & Abundant & Abundant \\
\hline Benthic assemblage & Diverse $^{4}$ & Oligotaxic & Oligotaxic \\
\hline Paleobathymetry & Middle neritic to bathyal & "Inner-middle neritic"5 & "Inner-middle neritic" 5 \\
\hline Oxygenation seafloor & Good to moderate & Poor (variable?) & Poor (variable?) \\
\hline
\end{tabular}

${ }^{1}$ Compilation of observations on four sections: Gebel Aweina, Gebel Duwi, Gebel Nezzi, Gebel Qreiya.

${ }^{2}$ Compilation of observations on the previous four sections plus Wadi Nukhl, and Ben Gurion (Israel).

${ }^{3}$ Lower $\mathrm{P} / \mathrm{B}$ ratios $(<50 \%)$ where dissolution has strongly affected the assemblages.

${ }^{4}$ Diversity increases with paleodepth.

${ }^{5}$ Paleobathymetric estimates for this interval based on benthic foraminifera are not reliable because of severe ecological disturbances. 
eral sections show conglomeratic stringers of macrofossils (gastropods, mollusks, shark-teeth), suggesting condensation levels. Morozovella is nearly absent in the planktic foraminifera assemblages, in contrast to over- and underlying beds, whereas praemuricate taxa like Igorina tadjikistanensis are suddenly abundant. The benthic assemblages are strongly dominated by Discorbis duwi, a species known mainly from middle-to-inner neritic deposits in Egypt, which may have had an opportunistic reproduction strategy. $\mathrm{P} / \mathrm{B}$ ratios are either extremely high $(>95 \% \mathrm{P})$ or very low $(<20 \% \mathrm{P})$ with values alternating within individual successions. Sea-floor oxygenation, surface productivity and diagenetic alteration probably all exerted control on these P/B-ratio fluctuations. In an earlier study on Gebel Aweina, this interval has been interpreted as a low stand after sea-level fall (Speijer \& Schmitz 1998). The new data, however, suggest a more complex scenario, which on a local scale is strongly reminiscent of the events taking place in the same basin some 5 m.y. later.

Discussion. - In Egypt, both events are marked by the sudden spread of oxygen deficiency on the sea floor. During the late Paleocene this occurred basin-wide (middle neritic to bathyal); because of stratigraphic gaps it is not clear whether the deepest parts of the basin were also involved during the "middle" Paleocene event. However, not only benthic environments were perturbed, also surface waters experienced unusual conditions, indicating transient environmental anomalies in the entire water column. Sedimentologic features of both events (minor submarine erosion, sediment starvation, omission surfaces) may have resulted from sudden sea-level rise - associated with circulation changes - after long term sea-level fall.

All over a vast basin ( $2500 \mathrm{~km}$ wide) in southern Russia and central Asia (northern Tethyan margin), the late Paleocene event shows a comparable lithologic and biotic development. Deposition of the so-called "sapropelic unit" has likewise been related to sea-level rise after long-term fall (Gavrilov et al. 1997). The sea-level change in Egypt and the northern Tethys may correspond to sequence boundary Th 5 or Th $6 / \mathrm{Yp} 0$ of Hardenbol et al. (1998). Likewise, the "middle" Paleocene sea-level rise may correspond to the well-known Selandian transgression in western Europe above the Sel 1 sequence boundary (Hardenbol et al. 1998). Thus, the two events recognized in Egypt could perhaps correspond to the onsets of the two main transgressive phases recognized in the Paleocene of western Europe (Hardenbol et al. 1998). However, these correlations are as yet tentative and require further scrutiny.

A genetic link between transgression and the spread of oxygen deficiency on the shelves has been widely cited (Hallam \&
Wignall 1997), but the exact mechanisms are not well understood. Interestingly, most of the main extinction events within the Phanerozoic are to a considerable extent associated with transgressive spread of anoxia (Hallam \& Wignall 1997). Although the late Paleocene event was highly complex, anoxia and/ or dysoxia played an important part on the shelves and possibly also in the deep-sea.

Realizing that the "middle" Paleocene event in Egypt may well just be a local phenomenon related to a sea-level fluctuation, there are hints that it may also have occurred in conjunction with a brief oceanic warming event. Transient warming is indicated by migration patterns of the tropical dinoflagellate genus Apectodinium (Bujak \& Brinkhuis 1998) and by deep-sea biota and their stable isotope signals (Thomas \& Zachos this volume). If these events indeed correlate with the "middle" Paleocene event in Egypt, it could be regarded as a mild precursor of the late Paleocene event, which unlike the latter did not perturb the dynamic equilibrium of the geobiosphere.

Conclusion. - In Egypt, the late Paleocene event appears to have had a precursor during the "middle" Paleocene, both showing the same kind of sedimentary and biotic anomalies. Whether or not this event has any significance to early Paleogene climatic or biotic evolution on larger scales remains to be investigated.

Acknowledgements. - This research was supported by a fellowship from the Humboldt Foundation. I thank the DFG for travel support (Sp 612/1-1) and Tom Wagner (Bremen University) for TOC data.

\section{References}

Bujak, J.P. \& Brinkhuis, H., 1998: Global warming and dinocyst changes across the Paleocene/Eocene Epoch boundary. In M.-P. Aubry, S.G. Lucas \& W.A. Berggren (eds.): Late Paleocene-early Eocene climatic and biotic events in the marine and terrestrial records, 277-295. Columbia University Press.

Gavrilov, Y.O., Kodina, L.A., Lubchenko, I.Y. \& Muzylev, N.G., 1997: The late Paleocene anoxic event in epicontinental seas of Peri-Tethys and formation of the sapropelite unit; sedimentology and geochemistry. Lithology and Mineral Resources 32, 427-450.

Hallam, A. \& Wignall, P.B., 1997: Mass extinctions and their aftermath. Oxford University Press. 320 pp.

Hardenbol, J., Thierry, J., Farley, M.B., Jacquin, T., De Graciansky, P.-C. \& Vail, P.R., 1998: Mesozoic - Cenozoic sequence chronostratigraphic framework of European basins. In P.-C. De Graciansky, J. Hardenbol, T. Jacquin \& P.R. Vail. (eds.): Mesozoic and Cenozoic sequence stratigraphy of European basins, 3-14. Society of Economic Paleontologits and Mineralogists Special Publication 60.

Speijer, R.P. \& Schmitz, B., 1998: A benthic foraminiferal record of Paleocene sea level and trophic/redox conditions at Gebel Aweina, Egypt. Palaeogeography, Palaeoclimatology, Palaeoecology 137, 79-101.

R.P. Speijer, Department of Geosciences, Bremen University, P.O.Box 330440,DE-28334Bremen, Germany,speijer@unibremen.de. 